\title{
Study of Suitability of Containers and Rooting Media for Growth and Rooting of Coffee Seedlings (Coffea arabica cv. Chandragiri)
}

\author{
D.D. Srigandha*, J. Venkatesha, G. Raviraja Shetty, I.B. Biradar, \\ G. Manjunath and Sudeesh Kulkarni \\ Department of plantation, spices, medicinal and aromatic crops, $\mathrm{COH}$, \\ Bagalkot-587104, Karnataka, India \\ *Corresponding author
}

\section{A B S T R A C T}

Study of suitability of containers and rooting media for growth and vigour of

\section{Keywords}

Coffee, Containers, Media.

\section{Article Info}

Accepted:

07 September 2017

Available Online:

10 October 2017 coffee seedlings (Coffea arabica cv. Chandragiri) was conducted with an objective to evaluate the suitability of different containers for raising the seedlings and to find out most suitable media for better rooting and growth of coffee seedlings. Coffee seedlings were grown in different containers and media for a period of 6 months in nursery. It was revealed from the study that, the growth and vigour of coffee seedling is greatly influenced by different containers and media used for filling of containers. Coffee seedlings grown in root trainer containing red soil + sand + FYM + Pseudomonas fluorescens, PSB - Bacillus megaterium and Azospirillum recorded maximum leaf area $\left(60.695 \mathrm{~cm}^{2}\right)$, collar girth $(4.01 \mathrm{~mm})$, number of primary (238.6) and secondary roots (557.8) and dry weight (1.098 g) of roots at 180 days(at the time of transplanting to the main field).

\section{Introduction}

Coffee (Coffea sp.) belongs to family Rubiaceae. Coffee is the second important commodity in international trade, next to petroleum products in trade volume and value. Area under coffee plantation is 397.147 thousand hectares in India of which Karnataka accounts for 54.95 percent $(2,35,438$ ha.). India is producing 3,48,000 MT of coffee (2015-16 data) of which Robusta variety account for 2,44,500 MT of production (70.3\%), while Arabica accounted for 1,03,500 MT (29.7\%). The Karnataka leads in production $(2,51,520 \mathrm{MT})$ next top producer states are Kerala and Tamilnadu.
India exports $70-80$ per cent of its produce. Commercially coffee is propagated through seeds. There are various factors that influence the initial development of coffee growing in the field, such as the seedlings production process and, specially, the container and substrate used (Vallone et al., 2009).

Amongst the containers used in conventional coffee seedling production, one can first list black polyethylene bags. This container presents a disadvantage, such as the contamination of the environment by the plastic bags when they are not properly 
discarded and coiling of roots. Regarding the substrate, conventionally Forest soil: FYM: Sand $(6: 2: 1)$. But the availability of forest soil is difficult because of dwindling of forest area.

\section{Materials and Methods}

An experiment was conducted during 2016-17 at the College of Horticulture, Mudigere to know the suitable container and rooting media to grow quality coffee seedlings for large scale plantation programme. The required seeds were collected from Central Coffee Research Institute, Balehonnur.

An experiment was laid out in a two factorial randomized block design. Coffee cultivar Chandragiri was used. Seeds were sown in portrays and raised bed of $15 \mathrm{~cm}$ height and 1 $\mathrm{m}$ wide size at a distance of $2 \mathrm{~cm}$ between seeds and $10 \mathrm{~cm}$ between rows in primary nursery. Coffee seedlings of 45 days (topee stage) old were transplanted to secondary nursery into different containers and media as per the treatment.

\section{Results and Discussion}

\section{Leaf area $\left(\mathrm{cm}^{2}\right)$}

The effect of containers and rooting media was found to be significant at 180 days after sowing (Table 1). The maximum leaf area $\left(60.95 \mathrm{~cm}^{2}\right)$ was recorded in the seedlings raised in root trainer using the media red soil + sand $+\mathrm{FYM}+$ P. fluorescens + PSB Bacillus megaterium + Nitrifying Bacteria Azospirillum $\left(\mathrm{C}_{4} \mathrm{M}_{7}\right)$ and the least $\left(18.29 \mathrm{~cm}^{2}\right)$ was recorded in $\mathrm{C}_{3} \mathrm{M}_{1}$ which was on par with $\mathrm{C}_{3} \mathrm{M}_{4}\left(21.95 \mathrm{~cm}^{2}\right)$. This superiority could be attributed better nutrition, moisture, aeration facilitates better enlargement and elongation of cell result in better growth of leaf. This was also related to organic-rich potting medium (red soil + sand $+\mathrm{FYM}+$ P. fluorescens + PSB + Azospirillum) used in the study would have exhibited favourable physical and chemical properties in root trainers. In polybags with inadequate drainage, however, the same medium may have hindered root growth and consequently shoot growth of seedlings (Annapurna et al., 2004).

\section{Treatment detail}

\begin{tabular}{|c|c|c|c|}
\hline \multicolumn{2}{|c|}{ Factor I: Container } & \multicolumn{2}{|c|}{ Factor II: Media } \\
\hline Treatment & Container & Treatment & Media \\
\hline $\mathrm{C}_{1}$ & $\begin{array}{l}\text { Black polythene bag }\left(6 \times 9^{\prime \prime}\right) \\
\text { [Control] }\end{array}$ & $\mathrm{M}_{1}$ & $\begin{array}{l}\text { Red soil }+ \text { sand }+ \text { FYM in } 3: 1: 1 \text { ratio } \\
\text { (Control) }\end{array}$ \\
\hline $\mathrm{C}_{2}$ & Transparent polythene bag $\left(6 \times 99^{\prime \prime}\right)$ & $\mathrm{M}_{2}$ & Red soil + cocopeat + FYM in 3:1:1 ratio \\
\hline $\mathrm{C}_{3}$ & $\begin{array}{l}\text { Protray raised seedlings in black } \\
\text { polythene bag }(6 \times 9)\end{array}$ & $\mathrm{M}_{3}$ & Red soil + sand + vermicompost in $3: 1: 1$ \\
\hline $\mathrm{C}_{4}$ & Root trainers & $\mathrm{M}_{4}$ & Red soil + sand + pressmud in $3: 1: 1$ \\
\hline \multirow[t]{3}{*}{$\mathrm{C}_{5}$} & Raising in beds & $\mathrm{M}_{5}$ & $\mathrm{M}_{1}+$ Pseudomonas fluorescens $(5 \mathrm{~g} / \mathrm{kg})$ \\
\hline & & $\mathrm{M}_{6}$ & $\begin{array}{l}\mathrm{M}_{5}+\mathrm{VAM}-\text { Gigaspora gigantean } \\
(10 \mathrm{~g} / \mathrm{kg} \mathrm{FYM})\end{array}$ \\
\hline & & $\mathrm{M}_{7}$ & $\begin{array}{l}\mathrm{M}_{5}+\mathrm{PSB}-\text { Bacillus megaterium }(10 \mathrm{~g} / \mathrm{kg} \\
\mathrm{FYM})+\quad \text { Nitrifying Bacteria } \\
\text { Azospirillum }(10 \mathrm{~g} / \mathrm{kg} \mathrm{FYM})\end{array}$ \\
\hline
\end{tabular}


Table.1 Effect of containers, rooting media and their interaction on leaf area $\left(\mathrm{cm}^{2}\right)$ of coffee seedlings at 180 days after sowing

\begin{tabular}{|c|c|c|c|c|c|c|c|c|}
\hline & $\mathbf{M}_{1}$ & $\mathbf{M}_{2}$ & $\mathbf{M}_{3}$ & $\mathbf{M}_{4}$ & $\mathbf{M}_{5}$ & $\mathbf{M}_{6}$ & $\mathbf{M}_{7}$ & Mean \\
\hline $\mathrm{C}_{1}$ & 48.23 & 49.59 & 51.97 & 49.78 & 55.57 & 56.26 & 56.45 & 52.55 \\
\hline $\mathbf{C}_{2}$ & 34.80 & 38.30 & 40.98 & 49.41 & 41.36 & 51.35 & 56.66 & 44.69 \\
\hline $\mathbf{C}_{3}$ & 18.29 & 22.36 & 24.07 & 21.95 & 34.29 & 34.98 & 35.84 & 27.39 \\
\hline $\mathrm{C}_{4}$ & 49.83 & 57.73 & 44.94 & 52.49 & 52.77 & 54.89 & 60.95 & 53.37 \\
\hline $\mathrm{C}_{5}$ & 31.17 & 33.97 & 34.54 & 33.31 & 35.43 & 45.75 & 54.44 & 38.37 \\
\hline Mean & 36.46 & 40.39 & 39.30 & 41.38 & 43.88 & 48.64 & 52.87 & \\
\hline CV $(\%)=10.38$ & \multicolumn{4}{|c|}{ S.Em \pm} & \multicolumn{4}{|c|}{ CD at $5 \%$} \\
\hline Container (C) & \multicolumn{4}{|c|}{1.08} & \multicolumn{4}{|c|}{3.10} \\
\hline Media (M) & \multicolumn{4}{|c|}{1.27} & \multicolumn{4}{|c|}{3.67} \\
\hline Interaction $(\mathrm{C} \times \mathrm{M})$ & \multicolumn{4}{|c|}{2.85} & \multicolumn{4}{|c|}{8.21} \\
\hline
\end{tabular}

$\begin{array}{lll}\text { C: Container } & \text { M: Media } & \text { DAS: Days after sowing }\end{array}$

Table.2 Effect of containers, rooting media and their interaction on dry weight (g) of coffee seedlings roots at 180 days after sowing

\begin{tabular}{|c|c|c|c|c|c|c|c|c|}
\hline \multicolumn{9}{|c|}{180 DAS } \\
\hline & $\mathbf{M}_{1}$ & $\mathbf{M}_{2}$ & $\mathbf{M}_{3}$ & $\mathbf{M}_{4}$ & $\mathbf{M}_{5}$ & $\mathbf{M}_{6}$ & $\mathbf{M}_{7}$ & Mean \\
\hline $\mathbf{C}_{1}$ & 0.400 & 0.430 & 0.478 & 0.425 & 0.493 & 0.515 & 0.524 & 0.466 \\
\hline $\mathbf{C}_{2}$ & 0.400 & 0.414 & 0.427 & 0.478 & 0.506 & 0.525 & 0.591 & 0.477 \\
\hline $\mathrm{C}_{3}$ & 0.403 & 0.419 & 0.489 & 0.404 & 0.502 & 0.525 & 0.541 & 0.469 \\
\hline $\mathrm{C}_{4}$ & 0.490 & 0.496 & 0.449 & 0.524 & 0.850 & 0.959 & 1.098 & 0.695 \\
\hline $\mathrm{C}_{5}$ & 0.485 & 0.486 & 0.475 & 0.512 & 0.615 & 0.785 & 0.800 & 0.594 \\
\hline Mean & 0.435 & 0.449 & 0.463 & 0.468 & 0.593 & 0.661 & 0.710 & \\
\hline $\operatorname{CV}(\%)=12.88$ & \multicolumn{4}{|c|}{ S.Em \pm} & \multicolumn{4}{|c|}{ CD at 5\% } \\
\hline Container (C) & \multicolumn{4}{|c|}{0.022} & \multicolumn{4}{|c|}{0.070} \\
\hline Media (M) & \multicolumn{4}{|c|}{0.026} & \multicolumn{4}{|c|}{0.080} \\
\hline Interaction $(\mathrm{C} \times \mathrm{M})$ & \multicolumn{4}{|c|}{0.060} & \multicolumn{4}{|c|}{0.173} \\
\hline
\end{tabular}
C: Container M: Media
DAS: Days after sowing
NS: Non significant

\section{Dry weight of roots}

The dry weight of roots recorded maximum $(1.098 \mathrm{~g})$ in root trainer filled with red soil + sand $+\mathrm{FYM}+P$. fluorescens $+\mathrm{PSB}+$ Azospirillum $\left(\mathrm{C}_{4} \mathrm{M}_{7}\right)$ and the least $(0.400 \mathrm{~g})$ was recorded in $\mathrm{C}_{1} \mathrm{M}_{1}$ at 180 days after sowing respectively (Table 2). Similar result was obtained by Biradar et al., (2006) when endophytic fungi VAM (Glomus fasciculatum) were inoculated with other microbial cultures especially the Azospirillum, P-Solubilizer and N-PGPR in coffee seedlings compared to individual inoculations. This container have open bottom and vertical ribs which avoid root coiling and allow for free flow of air resulting in proliferation of lateral roots (Saravanan et al., 2013) and there by higher dry weight of roots.

Coffee seedlings can be successfully grown in root trainer of $160 \mathrm{cc}$ using red soil + FYM + Sand + Pseudomonas fluorescens $(5 \mathrm{~g} / \mathrm{kg}$ FYM) + PSB - Bacillus megaterium $(10 \mathrm{~g} / \mathrm{kg}$ FYM) + Nitrifying Bacteria - Azospirillum $(10 \mathrm{~g} / \mathrm{kg}$ FYM) as media. 


\section{References}

Annapurna, D., Rathore, T. S. and Geeta, J., 2004, Effect of container type and size on the growth and quality of seedlings of Indian sandalwood (Santalum album L.). Aust. Forestry, 67(2): 82-87.

Anonymous, 2017, www.indiacoffee.org/ database-coffee.

Biradar, I. B., Muralidhara, H. R., Sudhakar, S. B. and Raghuramulu, Y., 2006, Role of biofertilizers and PGPR on growth and development of coffee seedlings. Journal of Coffee Research, 34(1/2): 57-63.
Saravanan, T. S., Rajendran, K., Uma, M. and Chezhian, P., 2013, Effects of bioinoculants on quality seedling production and nutrient uptake of casuarinas equisetifolia forst.grown in decomposed coir pith. Microbiol. Res. Agroecosystem Manage, pp. 141-154.

Vallone, H. S., Rubens, J. G., Antonio, N. G. M., Carlos, A. S. S., Fabio, P. D. and Alex, M. C., 2009, Recipients and substrates in the production of seedlings and initial development of coffee trees after planting. Science and Agrotechnology, 33(5): 1327-1335.

\section{How to cite this article:}

Srigandha, D.D., J. Venkatesha, G. Raviraja Shetty, I.B. Biradar, G. Manjunath and Sudeesh Kulkarni. 2017. Study of Suitability of Containers and Rooting Media for Growth and Rooting of Coffee Seedlings (Coffea arabica cv. Chandragiri). Int.J.Curr.Microbiol.App.Sci. 6(10): 527-530. doi: https://doi.org/10.20546/ijcmas.2017.610.064 